\title{
CRITICAL SUCCESS FACTORS AND THEIR INFLUENCE IN ERP IMPLEMENTATION SUCCESS OF ORGANIZATIONAL PERFORMANCE
}

\author{
Marina Hassan ${ }^{1,2}$, Marzanah A. Jabar ${ }^{2}$, Fatimah Sidi ${ }^{3}$, Yusmadi Yah Jusoh ${ }^{4}$, Salfarina Abdullah ${ }^{5}$ \\ ${ }^{1}$ Department of Computer Science, Faculty of Communication, Visual Art and Computing, Universiti Selangor \\ ${ }^{2}$ Department of Information System and Software Engineering, Faculty of Computer Science and Information Technology, Universiti \\ Putra Malaysia \\ *Corresponding Author Email: marina@unisel.edu.my,marzanah@upm.edu.my,fatimah@upm.edu.my,yusmadi@upm.edu.my, \\ salfarina@upm.edu.my
}

This is an open access article distributed under the Creative Commons Attribution License, which permits unrestricted use, distribution, and reproduction in any medium, provided the original work is properly cited.

\section{ARTICLE DETAILS}

Article History:

Received 12 December 2017 Accepted 10 January 2018 Available online 19 February 2018

\begin{abstract}
Effectiveness and efficiency of ERP execution is depending on the organization implementation. Every company that embarks on ERP execution will definitely hope that the execution will be success and effective. The concept of Critical Success Factors (CSFs) early emerged in 1961. Many studies have been conducted in order to analyze on the most CSFs. Few only intended directly to focus on organizational performance. A conceptual model will be developing to show the relationship between all the selected CSFs towards organizational performance in making sure the successful of ERP implementation in the organization. Systematic Literature Review (SLR) has been done in order to gain the CSFs. Completely target CSFs will be list out and traceability matrix table will be produce due to the priority of organizational performance. Pilot study has been conducting to proof the conceptual model suggest. A questionnaire has been distributed to 30 industry respondents. Results from this questionnaire survey than will demonstrate either the CSFs is really effect the successful execution of ERP in organizational performance or need to do changes based on the outcome. This paper proposes specific CSFs that influence directly to ERP execution success towards organizational performance. These will be very useful to organization in order to check on the organizational performance towards the successful implementation of ERP.
\end{abstract}

\section{KEYWORDS}

ERP critical success factors, Organizational Performance, ERP execution.

\section{INTRODUCTION}

Enterprise Resource Planning (ERP) software is widely used in many organization. The concept of Critical Success Factors (CSFs) emerged in 1961. Reference stated that influenced the contemporary use of CSFs as a tool to identify management's information needs and strategic priori-ties $[1,2]$. The large body of research identifying CSFs seems to have reached a broad consensus regarding which key factors can have a significant influence on the ERP implementation process. The findings of this research literature are summarized in Table 1.

Although the concept of CSF has been studied in a broad range of contexts, it appears that the role of CSFs in project success and performance outcome has attracted little specific attention. As discussed and defined earlier, a factor can only be termed a CSF if attending to this factor in a satisfactory manner results in performance improvements. Therefore, merely identifying a possibly important factor is not sufficient to constitute a CSF. The problem of establishing whether a CSF is really critical is further compounded by the multidimensional contexts in which 'success' and 'performance' may be measured, such as by user satisfaction or successful comple-tion of a project, or through the tangible and intangible benefits to an organization.

We find that only a few studies have attempted to investigate the effect of proposed CSFs on implementation success and/or organizational performance improvements. Noticeable examples include whose study found that leadership and business process reengineering were significant predictors of ERP adoption performance, and who found that organizational change and vendor support had a positive influence on operational efficiency and economic results, in other words, ERP system output performance $[3,4]$.

Reference identified various CSFs that have two way interactive relationships with implementation success [5]. Also stated that having a critical to manage for overall ERP project success is appointing a full-time project manager, having a project champion and providing training to staff [6]. Other researchers have produced evidence of positive associations between having business vision and external expertise and ERP system success and also implementation quality and organizational readiness lead to post-implementation success [7].

From the above we conclude that while some research work has been done to understand the influence of CSFs, the output is fragmented and based on a variety of success and performance measures. The output fragmentation leads to difficulties in the consolidation, generalizability and clear understanding of the effect of CSFs on implementation and post implementation performance outcomes. We have chosen to examine the effect of four CSFs that have consistently been considered central to implementation success, including those indicated by $[8,9]$. These factors are Project Management (PM), Training and Education (TED), Business Process Re-engineering (BPR) and System Integration (SI).

The selection of these four factors for this study was based on the literature that has indicated their importance for the success of ERP projects, and has shown that their relationship to success has not been empirically well established. Further, the divergence in measurement of suc-cess or performance has resulted in fragmentary understanding of the role of the selected factors in achieving success and performance gains from ERP projects, thus merits further research atten-tion.

Except for the TED factor, it is important to note that the other three factors have not been examined previously in terms of their relationship to important success measures of project deliverables related to success of the implementation process, such as being on time, on budget and meeting user expectations. By conceptually distinguishing the successful implementation and organizational performance as two separate outcomes of ERP projects, we aim to provide empirical evidence of the direct influence of the chosen CSFs on organizational performance and the mediating role of implementation success on the relationship between CSFs and the organization-al performance of ERP projects. 


\section{RESEARCH METHODS}

From the discussions of introduction above, we find that few researches have described and verified the relationships between organizational performance and its antecedents for CSF. Identifying CSF for ERP implementation to give impact on organizational performance is a critical issue to be discussed in increasing the organizational performance. The methodology on this research consists of two major parts: systematic literature review and also pilot study. Systematic literature review begins with identifying critical factors that will give impact on oragizational performance. From this method, research model may be derived from the result of pilot study and some hypotheses proposed. Survey method is designed to verify the model as well as these hypotheses. Table 1 summarizes the findings on the relationship between CSFs and implementation success and/or performance outputs of ERP. It additionally includes indications of the way that implementation success has been measured in the literature and has, therefore lead to the approach followed in this study.

Table 1: List of critical success factors (CSFs) to ERP implementation/ performance.

\begin{tabular}{|c|c|c|}
\hline $\begin{array}{l}\text { Identified as a CSF to ERP } \\
\text { implementation stage }\end{array}$ & $\begin{array}{l}\text { References of studies that } \\
\text { have identified the CSF }\end{array}$ & $\begin{array}{l}\text { The studies given below found } \\
\text { a positive relationship between } \\
\text { the CSF and the implementa- } \\
\text { tion success / Performance Im- } \\
\text { plementation success / Perfor- } \\
\text { mance was measured in the } \\
\text { studies given }\end{array}$ \\
\hline $\begin{array}{l}\text { - Cultural and structural } \\
\text { changes } \\
\text { - Readiness } \\
\text { - Organizational culture }\end{array}$ & $\begin{array}{l}\text { - Dezdar and Sulaiman } \\
\text { (2009) } \\
\text { - Motwani et al. (2002) }\end{array}$ & \\
\hline $\begin{array}{l}\text { - Project management and } \\
\text { evaluation } \\
\text { - Project management ca- } \\
\text { pabilities. }\end{array}$ & $\begin{array}{l}\text { - Dezdar and Sulaiman } \\
\text { (2009) } \\
\text { - Finney and Corbett (2007) } \\
\text { - Snider et al. (2009) } \\
\text { - Somers and Nelson (2004) } \\
\text { - Motwani et al. (2002) }\end{array}$ & $\begin{array}{l}\text { - A success index (El Sawah et } \\
\text { al., 2008) } \\
\text { - implementation quality, } \\
\text { which in turn impacts post } \\
\text { implementation success } \\
\text { measured by operational and } \\
\text { managerial benefits }\end{array}$ \\
\hline - Business plan and vision. & $\begin{array}{l}\text { - Al-Mashari et al. (2003) } \\
\text { - Dezdar and Sulaiman } \\
\text { (2009) } \\
\text { - Finney and Corbett (2007) } \\
\text { - Nah and Delgado (2006) } \\
\text { - Ifinedo and Nahar (2009) }\end{array}$ & $\begin{array}{l}\text { - Five dimensions of system } \\
\text { quality, information quality, } \\
\text { individual impact, workgroup } \\
\text { impact, organizational im- } \\
\text { pact. }\end{array}$ \\
\hline $\begin{array}{l}\text { - Enterprise wide commu- } \\
\text { nication } \\
\text { - Strong communication } \\
\text { inwards and outwards } \\
\text { - Communication plan }\end{array}$ & $\begin{array}{l}\text { - Dezdar and Sulaiman } \\
\text { (2009) } \\
\text { - Finney and Corbett (2007) }\end{array}$ & \\
\hline $\begin{array}{l}\text { - Project champion } \\
\text { - Sponsor }\end{array}$ & $\begin{array}{l}\text { - Dezdar and Sulaiman } \\
(2009) \\
\text { - Finney and Corbett (2007) } \\
\text { - Bradley (2008) }\end{array}$ & $\begin{array}{l}\text { - A three-item measure as- } \\
\text { sessing completion on time, } \\
\text { within budget and organiza- } \\
\text { tional impact }\end{array}$ \\
\hline $\begin{array}{l}\text { - Business Process Reengi- } \\
\text { neering } \\
\text { - Minimum customization } \\
\text { - Software configuration } \\
\text { - Integration of business } \\
\text { processes }\end{array}$ & $\begin{array}{l}\text { - Al-Mashari et al. (2003) } \\
\text { - Bangi et al. (1999) } \\
\text { - Dezdar and Sulaiman } \\
\text { (2009) } \\
\text { - Finney and Corbett (2007) } \\
\text { - Motwani et al. (2005) } \\
\text { - Nah and Delgado (2006) } \\
\text { - Somers and Nelson (2004) } \\
\text { - Vathanophas (2007) } \\
\text { - Z Zabjek et al., 2009 }\end{array}$ & $\begin{array}{l}\text { - A two item measure that as- } \\
\text { sess impact on business per- } \\
\text { formance and as per expected } \\
\text { results. }\end{array}$ \\
\hline $\begin{array}{l}\text { - Training employees } \\
\text { - User training and educa- } \\
\text { tion } \\
\text { - Job redesign }\end{array}$ & $\begin{array}{l}\text { - Dezdar and Sulaiman } \\
\text { (2009) } \\
\text { - Finney and Corbett (2007) } \\
\text { - Snider et al. (2009) } \\
\text { - Vathanophas (2007) } \\
\text { - Bradford and Florin, } 2003 \\
\text { - Bradley, } 2008\end{array}$ & $\begin{array}{l}\text { - User satisfaction and ERP } \\
\text { benefits } \\
\text { - A three-item measure as- } \\
\text { sessing completion on time, } \\
\text { within budget and organiza- } \\
\text { tional impact }\end{array}$ \\
\hline $\begin{array}{l}\text { - Teamwork and project } \\
\text { team composition } \\
\text { - Competence and com- } \\
\text { pensation } \\
\text { - Selecting the right em- } \\
\text { ployees } \\
\text { - Balanced team } \\
\text { - Small internal teams }\end{array}$ & $\begin{array}{l}\text { - Bingi et al. (1999) } \\
\text { - Dezdar and Sulaiman } \\
\text { (2009) } \\
\text { - Finney and Corbett } \\
\text { (2007) } \\
\text { - Plant and Willcocks } \\
\text { (2007) } \\
\text { - Snider et al. (2009) } \\
\text { - Somers and Nelson } \\
\text { (2004) } \\
\text { - Soja (2006) } \\
\text { - Wang et al. (2008) }\end{array}$ & $\begin{array}{l}\text { - A synthetic measure that in- } \\
\text { cluded scope, duration, finan- } \\
\text { cial budget, user satisfaction, } \\
\text { and goals achievement } \\
\text { - Impact on decision making } \\
\text { and control, efficiency and } \\
\text { profitability }\end{array}$ \\
\hline - System quality & $\begin{array}{l}\text { - Dezdar and Sulaiman } \\
\text { - Ram et al., (2013b) }\end{array}$ & $\begin{array}{l}\text { - A four-item measure that as- } \\
\text { sess implementation success } \\
\text { by: project completion on } \\
\text { time/schedule, within budget, } \\
\text { as per expectations, and as per } \\
\text { user satisfaction }\end{array}$ \\
\hline - ERP vendor support & $\begin{array}{l}\text { - Bingi et al. (1999) } \\
\text { - } \begin{array}{l}\text { Dezdar and Sulaiman } \\
(2009)\end{array} \\
\text { - } \begin{array}{l}\text { Somers and Nelson } \\
(2004)\end{array}\end{array}$ & $\begin{array}{l}\text { - Impact on decision making } \\
\text { and control, efficiency and } \\
\text { profitability }\end{array}$ \\
\hline
\end{tabular}

\begin{tabular}{|c|c|c|}
\hline & - Wang et al. (2008) & \\
\hline $\begin{array}{l}\text { - ERP consultants } \\
\text { - Consultant quality } \\
\text { - Use of consultants } \\
\text { - Qualified consultants }\end{array}$ & $\begin{array}{l}\text { - Finney and Corbett } \\
\text { - } 2007) \text { amers and Nelson } \\
(2004) \\
\text { - Snider et al. (2009) } \\
\text { - Wang et al. (2008) }\end{array}$ & $\begin{array}{l}\text { - Impact on decision making } \\
\text { and control, efficiency and } \\
\text { profitability }\end{array}$ \\
\hline $\begin{array}{l}\text { - System integration } \\
\text { - User involvement } \\
\text { - Participation and support }\end{array}$ & $\begin{array}{l}\text { - Al-Mashari et al. (2003) } \\
\text { - Bingi et al. (1999) } \\
\text { - Dezdar and Sulaiman } \\
\text { (2009) } \\
\text { - Wang et al. (2008) }\end{array}$ & $\begin{array}{l}\text { - Impact on decision making } \\
\text { and control, efficiency and } \\
\text { profitability }\end{array}$ \\
\hline $\begin{array}{l}\text { - Sustained (top) manage- } \\
\text { ment support / commit- } \\
\text { ment }\end{array}$ & $\begin{array}{l}\text { - Dezdar and Sulaiman } \\
(2009) \\
\text { - Finney and Corbett } \\
(2007) \text { } \\
\text { - Nah and Delgado (2006) } \\
\text { - Plant and Willcocks } \\
\text { (2007) } \\
\text { - Snider et al. (2009) } \\
\text { El Sawah et al. (2008) } \\
\text { - Petroni (2002) }\end{array}$ & $\begin{array}{l}\text { - A success index } \\
\text { - Benefits achieved in im- } \\
\text { proved customer satisfaction, } \\
\text { planning and inventory man- } \\
\text { agement, improved effi- } \\
\text { ciency, know-how and com- } \\
\text { petence, organisational cli- } \\
\text { mate }\end{array}$ \\
\hline $\begin{array}{l}\text { - Interdepartmental (enter- } \\
\text { prise-wide) cooperation } \\
\text { - Communication }\end{array}$ & $\begin{array}{l}\text { - Dezdar and Sulaiman } \\
\text { (2009) } \\
\text { - Plant and Willcocks } \\
\text { (2007) } \\
\text { - Somers and Nelson } \\
(2004)\end{array}$ & \\
\hline $\begin{array}{l}\text { - Steering committee } \\
\text { - Management of expecta- } \\
\text { tions } \\
\text { - Careful package selection }\end{array}$ & $\begin{array}{l}\text { - Somers and Nelson } \\
(2004) \\
\text { - Dezdar and Sulaiman } \\
(2009) \\
\text { - Finney and Corbett } \\
\text { (2007) } \\
\text { - Somers and Nelson } \\
\text { (2004) } \\
\text { - Vathanophas (2007) }\end{array}$ & \\
\hline $\begin{array}{l}\text { - Data analysis, conversion } \\
\text { and integrity }\end{array}$ & 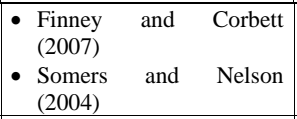 & \\
\hline $\begin{array}{l}\text { - Charismatic leadership fit } \\
\text { between ERP and organi- } \\
\text { zation }\end{array}$ & $\begin{array}{l}\text { - Wang et al. (2005) } \\
\text { - Baki and C- akar (2005) } \\
\text { - El Sawah et al. (2008) } \\
\text { - Hong and Kim (2002) }\end{array}$ & $\begin{array}{l}\text { - a success index } \\
\text { - perceived deviation from the } \\
\text { expected project goals i.e., } \\
\text { cost, time, performance, ben- } \\
\text { efits }\end{array}$ \\
\hline $\begin{array}{l}\text { - Implementation strategy } \\
\text { \& time frame Vanilla } \\
\text { - ERP Build a business } \\
\text { case Implementation ap- } \\
\text { proach } \\
\text { - Organizational transfor- } \\
\text { mation } \\
\text { - Software migration }\end{array}$ & $\begin{array}{l}\text { - Finney and Corbett } \\
\text { (2007) } \\
\text { - Vathanophas (2007) }\end{array}$ & \\
\hline $\begin{array}{l}\text { - Formal project plan / } \\
\text { schedule }\end{array}$ & - Bingi et al. (1999) & \\
\hline
\end{tabular}

\section{Research Model and Hypotheses}

As discussed above, four CSFs were chosen, PM, TED, BPR and SI, to examine their effect on ERP implementation success (IMP) and organizational performance (OP). To facilitate this examination, a conceptual model showing the potential relationships of these four factors to IMP and OP was built and is presented in Figure 1. The relationships proposed in the model along with their associated research hypotheses are described in the following section.

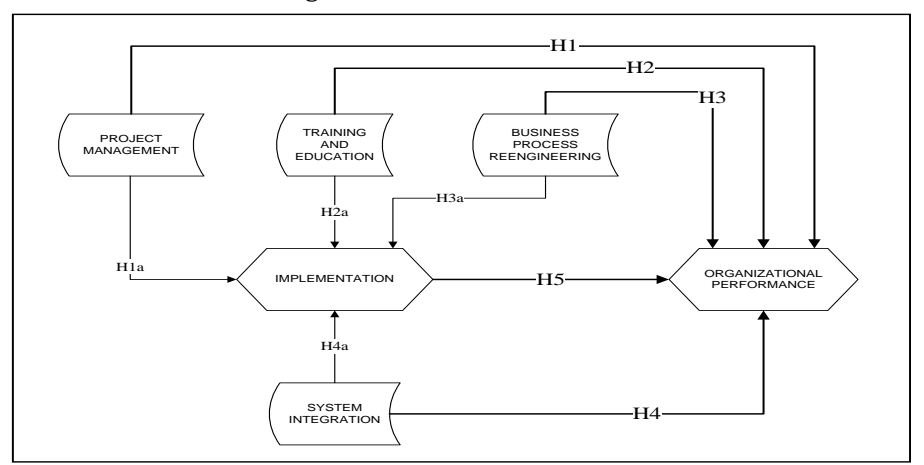

Figure 1: The proposed model 
The inherent complexity of the ERP projects and the high risk of failure necessitate employing formal tools, techniques and methodologies, such as PM methodologies, to improve the chances of project success Project management has been consistently found to be one of the major CSFs for successful implementation of ERP $[10,11]$.

While PM is considered critical to the success of the implementation process of ERP, intuitively its effect will extend beyond that of facilitating increased output value and/or the achievement of the objectives of the project. Successful PM is regarded as having a two-dimensional effect of:

\section{(a)Transforming 'resources into outputs;}

(b)Helping achieve project benefits in the form of performance improvements, cost reductions and other desired values established by stakeholders' interests in a particular project [12]

Recent research suggests that the effective use of PM practices and techniques because of their strategic and tactical dimensions could enable organizations to realize the expected benefits of projects [13]. Reference claimed that implementation of PM does indeed yield value to organizations; however, its magnitude may vary depending on the project context [14]. The value generated by the use of PM is multidimensional in nature. It is not just limited to monetary returns, but also includes intangible benefits in the form of organizational efficiencies and customer satisfaction [15]

While their research is still preliminary, reference found evidence to suggest that using PM processes, standards, methodologies and techniques often termed as "project management maturity" can lead to strategic advantage for an organization [16]. However, organizations must focus both on effectively developing tangible assets (such as PM maturity) and intangible assets (such as sharing know how) to use PM to gain benefits. The foregoing discussion shows that while some evidence exists albeit preliminary for the relationship between $\mathrm{PM}$ and $\mathrm{OP}$, fur-ther empirical investigations are required to confirm this and help understand the relationship more fully. Organizations can obtain the benefits of improved performance only if they are able to implement the ERP system successfully [17]. Reference noted that IMP is a key mediator and precursor to the achievement of OP [18]. Reference suggested that PM competence leads to project performance, which subsequently results in improved OP [19]. Based on the literature above, we argue that implementation success acts as a mediator between project management and performance outcome. It is an enabler of the achievement of :

H1: The use of PM for ERP projects is directly and positively associated with OP.

H1a: The influence of the use of PM on OP is mediated by the achievement of IMP.

\subsection{Training and Education (TED)}

Internalizing the knowledge embedded in ERP systems is a most critical strategy for achieving success in ERP projects [20]. User education and training serve as a medium to unpack and facilitate the transfer of explicit and tacit knowledge enshrined in the routines, practices and functions of ERP systems. TED is defined here as the continuous transfer of both tacit and explicit knowledge about the logic, concept, processes and function of the ERP systems. Effective training is considered very important to equip users with the necessary skills and tools to use an ERP system efficiently in their day-to- day activities [21].

A good TED program can help users employ the system to its full potential and can help organizations realize the full benefits of implementing an ERP system presented the results of a meta-analysis of 67 general studies that examined the relationship of training to human, organizational and financial performance $[22,23]$. They concluded that TED has a positive relationship with OP. In another study, TED was found to be positively associated with user satisfaction, thus leading to improved OP [24].

A suitable TED program can help organizations ensure effective knowledge management, which has a positive influence on management performance for organizations, as measured in terms of financial performance, business performance and organizational effectiveness [25]. Effective staff training and education enables organizations to realize financial gains [22]. In line with the resource based view (RBV), we argue that training programs that are designed to en-hance users' skills are vital to organizational efforts to develop human resource capabilities to achieve the organization's managerial, financial and performance targets [23]. The knowledge transfer during training sessions produces improved human system interaction and improved users' confidence, thus resulting in fewer problems in the the accomplishment of routine and mission-critical business tasks. As such, it is logical to hypothesize that a good TED program will result in improved OP. However, for users to be able to employ the system optimally, it is necessary that the system is implemented successfully. A number of studies have found that TED is one of the most important CSFs for ERP implementation success [26]. Therefore, it is reasonable to argue that TED will not only have a direct influence on $\mathrm{OP}$, but that its influence will also be mediated by the success of the implementation.

Based on the above argument, we contend that an effective TED program is expected to improve users' levels of comfort and their expertise and knowledge of the system. It is also expected to influence system success and post-implementation OP outcomes. Thus, this study in-vestigated the following hypotheses:

\section{H2: TED is directly and positively associated with $\mathrm{OP}$.}

\section{H2a: The influence of TED on OP is mediated by achieving IMP.}

\subsection{BUSINESS PROCESS RE-ENGINEERING (BPR)}

ERP applications embed best business practices, however, these generic processes may not be compatible with the business processes and practices of the adopting organizations. Organizations may thus be required to improve or reengineer their business processes to align them with an ERP's business model [27]. BPR is defined as 'the fundamental rethinking and radical redesign of business processes to achieve dramatic improvements in critical measures of performance such as cost, quality, service, job satisfaction and speed [28].

BPR is a strategy to create a conducive platform to facilitate successful ERP implementation. Therefore, it is not surprising that BPR has been found to be a critical factor in the early stages of the ERP implementation process [29]. The business process gap between organizational and ERP processes was found to be the likely cause of ERP project failure [23]. Various authors have found a significant positive relationship between BPR and such factors as ERP overall success, performance improvements, and internal process efficiency benefits [30]. However, the findings of a study differed from these generally held views, as they found that BPR was not related to ERP implementation success [31].

Organizations perform BPR to restructure processes to eliminate inefficient and non-value adding operations and to align their ongoing business activities with industry best practices [32]. BPR has resulted in OP benefits in the areas of finance, customer service and growth sustenance [33]. A business process change was found to correlate with productivity, as measured by sales per employee claimed that the introduction of information technology must be accompanied by process redesign to gain productivity improvements [34]. Similarly, found that IT capital investment should be combined with BPR to achieve profitability [33]. Successful business process changes can be important facilitators to achieve implementation project success and post-implementation performance gains [35].

The empirical evidence cited above establishes that performing BPR is expected to signif-icantly improve the chances of ERP IMP and post implementation OP. Given that a BPR exercise may precede implementation, it is expected that IMP will mediate the relationship between BPR and the realization of OP improvements. Thus, the following hypotheses were postulated:

H3: Undertaking BPR is directly and positively associated with OP.

H3a: The influence of BPR on OP is mediated by achieving IMP.

\subsection{SYSTEM INTEGRATION (SI)}

On seeking to implement ERP, it is not uncommon for organizations to prefer to retain some existing specialized software packages, either due to unique business needs or regulatory requirements [36]. Such a situation necessitates the integration of ERP with these applications. In addition, organizations seek competitive advantage by aligning with other organizations, usually for their non core business activities, and thus may intend to integrate ERP with partner systems. However, this required integration is a complex process, particularly given ERP's modular struc-ture [37].

Middleware technologies, such as enterprise application integration (EAI), supplement integration requirements [38]. However, middleware products concentrate on technical interoperability, rather than linking business processes, thus organizations may require further system development 
activities to build their custom integration interfaces. In addition to the above problems, the cross module integration makes the process more complex [39].

Reference defined the term 'system integration' as 'the capability to integrate a variety of different system functionalities' [40]. Ideally, organizations view ERP as a single solution covering all business functions [41]. Proposed that a feasible way to achieve this would be a system that reduces customization and allows organizations to select the best modules from different vendors and integrate them using EAI. With the ongoing development in integration technologies, cloud computing, software as a service (SaaS) initiatives, and web-based ERP, it is expected that organizations will continue implementing ERP, and will use various integration tools to link their ERP with the business systems and applications external to ERP.

With the implementation of tightly integrated ERP systems, it is expected that organizations will achieve high information visibility and improved decision making across the entire supply chain. Organizations are expected to leverage the integration capabilities of the system to gain better control, improved operations and better cost control, thus leading to improvements in $\mathrm{OP}$ [42].

System integration is considered one of the CSFs at the deployment stage of ERP this finding reinforces the importance of ensuring that all the ERP modules are interfaced for the seamless operation of ERP systems, thus allowing successful implementation [43]. It is therefore expected that IMP will mediate the influence of system integration on OP. In consideration of the above arguments, the following hypotheses were proposed:

H4: SI is directly and positively associated with OP.

H4a: The influence of SI on OP is mediated by achieving IMP.

\subsection{IMPLEMENTATION SUCCESS AND ORGANIZATIONAL PERFORMANCE}

An implementation project is considered successful when the implemented systems go live and operate 'with agreed upon requirements, and delivered within schedule and budget' success in the ERP context has been measured from multidimensional perspectives such as, organizational performance improvements, and the completion of the project within the required time, budget and agreed upon deliverables [44].

Proposed a framework for managers to assess the benefits of implementing enterprise systems [45]. However, achieving performance benefits depends on the implementation success of ERP projects. Some researcher proposed that information and communication technology (ICT) innovations in organizations follow a four stage process: adoption, implementation, use and effects and so support the belief that implementation precedes output performance [46]. A group researchers use such a stage based approach in their work and indicated that the introduction of innovations into organizations, not unexpectedly, leads to improved organizational performance $[47,48]$.

The stage-based modelling approach has been popular for examining innovation in information system, and a number of studies have investigated models with adoption, implementation, use and benefit stages. The ERP literature has been predominantly implementation focused the use of CSFs is one of the key implementation strategies employed by organizations to focus on and manage the few key areas in the implementation process that could help achieve a successful implementation outcome [49]. Some researcher provided evidence that the use of CSFs indeed helps organizations achieve the benefits of using enterprise systems [50].

In their IS success model, posit that paying attention to key antecedent factors leads to use and user satisfaction of an information system and the realization of individual and organiza-tional outcomes [46]. However, we note that in the IS success model the antecedent factors directly influence use of the system, once the implementation stage is successfully accomplished. Given the focus of our study is on examining the CSFs' role on the organizational performance directly or mediated through the success of implementation stage, it can be seen that the IS Success model is not fully appropriate for the objectives of our study. But overall, the IS success model supports paying attention to antecedent factors in order to realize individual and organizational outcomes.

Based upon the previous work that supports the sequential, stage-based models of information system by which they enter organizations and can lead to output performance, we argue that organizational performance should be measured as an outcome of the implementation success of ERP. This is supported examined the post-ERP implementation performance of
' И

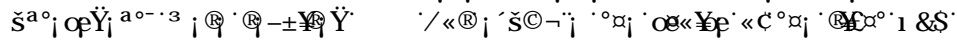

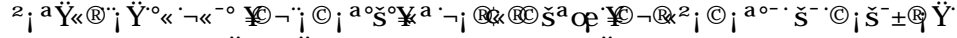

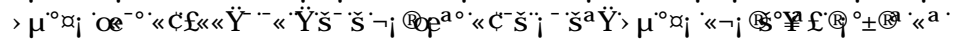

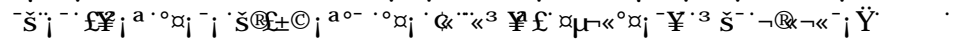

प и

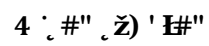

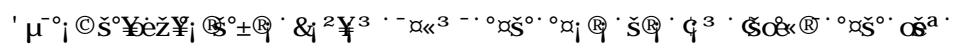

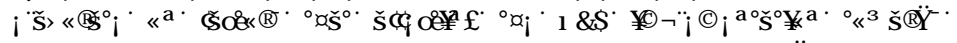

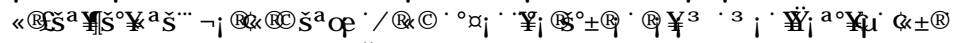

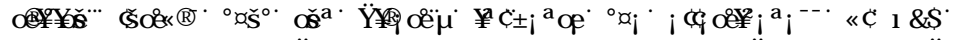

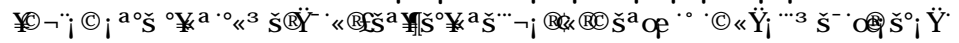
पएW

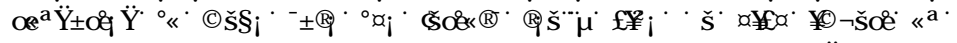

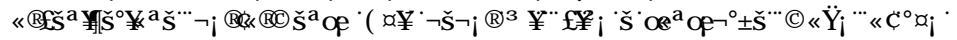

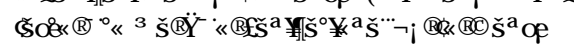

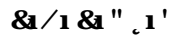

ôr

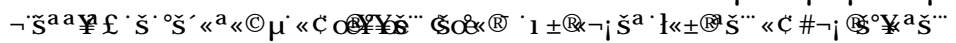

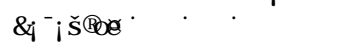

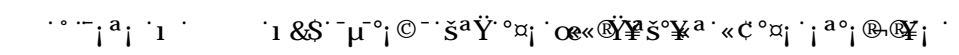

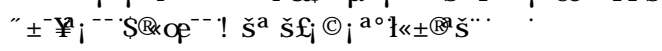

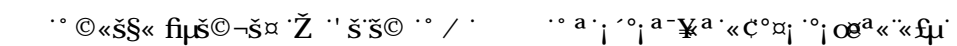
एس

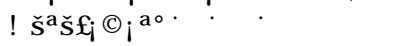

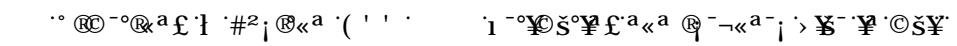

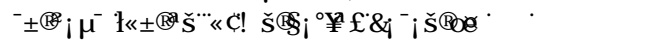

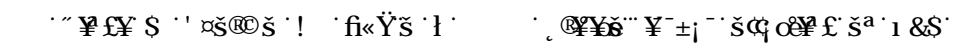
四

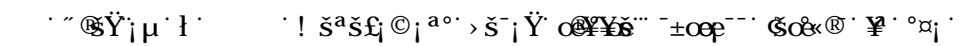
m

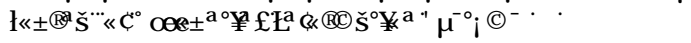

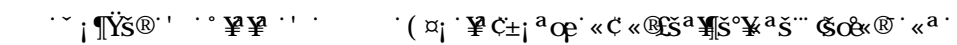

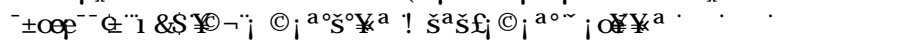

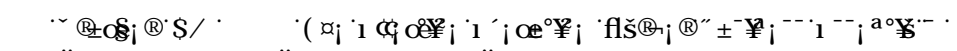

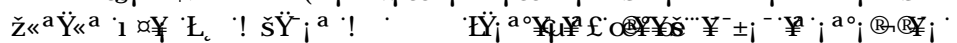

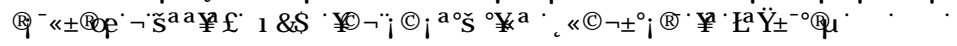

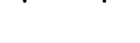

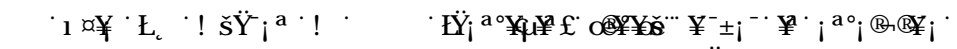

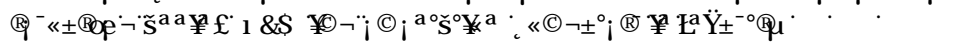
ии \G

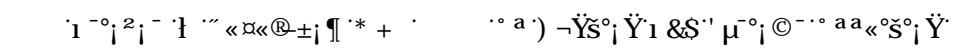

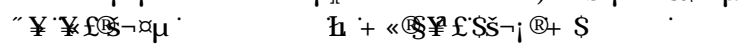

ôr

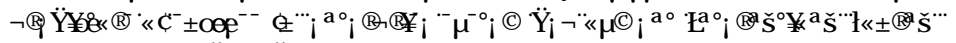

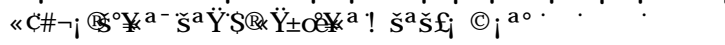

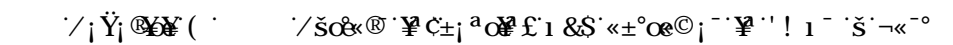
田

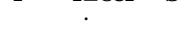

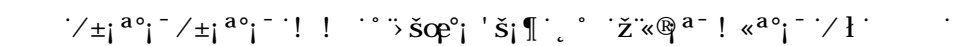

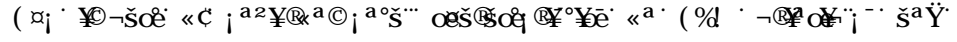

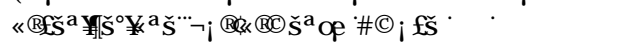

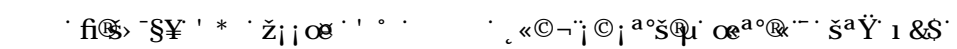

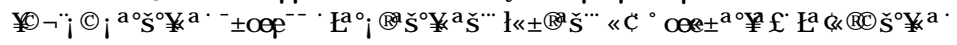

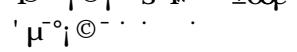

ôr

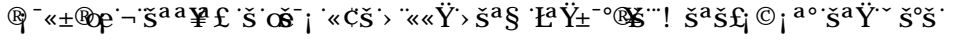

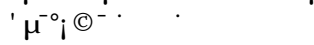

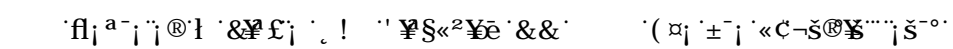
प

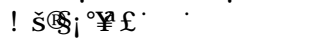

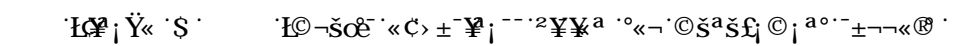

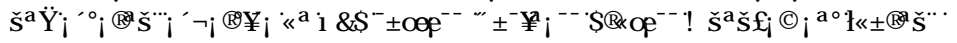

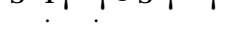


[18] Ifinedo, P., Rapp, B., Ifinedo, A., Sundberg, K. 2010. Relationships among ERP post-implementation success constructs: an analysis at the organizational level. Computers in Human Behavior, 26, 1136-1148.

[19] Ke, W., Wei, K.K. 2008. Organizational culture and leadership in ERP implementation. De-cision Support Systems, 45 (2), 208-218.

[20] Klein, R. 2007. An empirical examination of patient-physician portal acceptance. European Journal of Information Systems, 16 (6), 751-760.

[21] Law, C.C.H., Ngai, E.W.T. 2007b. An investigation of the relationships between organiza-tional factors business process improvement, and ERP success. Bench-marking: An International Journal, 14 (3), 387-406.

[22] Liu, P.L. 2011. Empirical study on influence of critical success factors on ERP knowledge management on management performance in high-tech industries in Taiwan. Expert Systems with Applications, 38, 10696-10704.

[23] Motwani, J., Mirchandani, D., Madan, M., Gunasekaran, A. 2002. Successful implementa-tion of ERP projects: evidence from two case studies. International Journal of Production Eco-nomics, 75 (1-2), 83-96.

[24] Munns, A., Bjeirmi, B.F. 1996. The role of project management in achieving project success. International Journal of Project Management, 14, 81-87.

[25] Nah, F.F.H., Delgado, S. 2006. Critical success factors for enterprise resource planning im-plementation and upgrade. Journal of Computer Information Systems, 46 (5), 99.

[26] Ngai, E.W.T., Law, C.C.H., Wat, F.K.T. 2008. Examining the critical success factors in the adoption of enterprise resource planning. Computers in Industry, 59 (6), 548-564.

[27] Nicolaou, A.I. 2004. Firm performance effects in relation to the implementation and use of enterprise resource planning systems. Journal of Information Systems, 18, 79-105.

[28] Nunnally, J., Bernstein, I. 1994. Psychometric theory. In: Psychometric Theory. McGraw-Hill, NewYork, NY.

[29] Plant, R., Willcocks, L. 2007. Critical success factors in international ERP imple-mentations: a case research approach. Journal of Computer Information Systems, 47 (3), 60.

[30] Rabaa'i, A.A., Bandara, W., Gable, G.G. 2009. ERP systems in the higher education sector: a descriptive case study. Paper Presented at the 20th Australian Conference on Information Sys-tems, Melbourne, Australia.

[31] Ram, J., Corkindale, D., Wu, M.L. 2013a. Enterprise resource planning adoption: structural equation modelling analysis of antecedents. Journal of Computer Information Systems, (Forth-coming).

[32] Rockart, J.F. 1978. A New Approach to Defining the Chief Executive's Information Needs. MIT Working Paper, CISR 37 (WP 1008-78).

[33] Shi, Q. 2011. Rethinking the implementation of project management: a value adding path map approach. International Journal of Project Management, 29, 295-302.

[34] Snider, B., Da Silveira, G.J.C., Balakrishnan, J. 2009. ERP implementation at SMEs: analysis of five Canadian cases. International Journal of Operations \& Produc-tion Management, 29 (1), 4-29.

[35] Soja, P. 2006. Success factors in ERP systems implementations: lessons from practice. Jour-nal of Enterprise Information Management, 19 (4), 418433.

[36] Somers, T.M., Nelson, K.G. 2003. The impact of strategy and integration mechanisms on enterprise system value: empirical evidence from manufacturing firms. European Journal of Oper-ational Research, 146 (2), 315-338.

[37] Su, Y., Yang, C. 2010. Why are enterprise resource planning systems indispensable to supply chain management? European Journal of Operational Research, 203, 81-94.
[38] Thomas, J., Mullaly, M. 2006. Defining the value of project management. In: Search of Val-ue, PMI Research Conference. Project Management Institute, Montreal, Canada.

[39] Thomas, J., Mullaly, M. 2007. Understanding the value of project management: first steps on an international investigation in search of value. Project Management Journal, 38, 74-89.

[40] Wang, E.T.G., Shih, S.P., Jiang, J.J., Klein, G. 2008. The consistency among facilitating fac-tors and ERP implementation success: a holistic view of fit. The Journal of Systems and Soft-ware, 81, 1609-1621.

[41] Wetzels, M., Odekerken-Schroder, G., Van Oppen, C. 2009. Using PLS path modeling for assessing hierarchical construct models: guidelines and empirical illustration. Management In-formation Systems Quarterly, 33 (1), 11.

[42] Zhai, L., Xin, Y., Cheng, C. 2009. Understanding the value of project management from a stakeholder's perspective: case study of mega-project management. Project Management Journal, 40, 99-109.

[43] Zhu, Y., Li, Y., Wang, W., Chen, J. 2010. What leads to post-implementation success of ERP? An empirical study of the Chinese retail industry. International Journal of Information Management, 30 (3), 265-276.

[44] Motwani, J., Mirchandani, D., Madan, M., Gunasekaran, A. 2002. Successful implementa-tion of ERP projects: evidence from two case studies. International Journal of Production Eco-nomics, 75 (1-2), 83-96.

[45] Thomas, J., Mullaly, M. 2007. Understanding the value of project management: first steps on an international investigation in search of value. Project Management Journal, 38, 74-89.

[46] Liu, P.L. 2011. Empirical study on influence of critical success factors on ERP knowledge management on management performance in high tech industries in Taiwan. Expert Systems with Applications, 38, 10696-10704.

[47] Wang, E.T.G., Shih, S.P., Jiang, J.J., Klein, G. 2008. The consistency among facilitating fac-tors and ERP implementation success: a holistic view of fit. The Journal of Systems and Soft-ware, 81, 1609-1621.

[48] Wetzels, M., Odekerken-Schroder, G., Van Oppen, C. 2009. Using PLS path modeling for assessing hierarchical construct models: guidelines and empirical illustration. Management In-formation Systems Quarterly, 33 (1), 11.

[49] Zhu, Y., Li, Y., Wang, W., Chen, J. 2010. What leads to post-implementation success of ERP? An empirical study of the Chinese retail industry. International Journal of Information Management, 30 (3), 265-276.

[50] Snider, B., Da Silveira, G.J.C., Balakrishnan, J. 2009. ERP implementation at SMEs: analysis of five Canadian cases. International Journal of Operations \& Produc-tion Management, 29 (1), 4-29.

[51] Nicolaou, A.I. 2004. Firm performance effects in relation to the implementation and use of enterprise resource planning systems. Journal of Information Systems, 18, 79-105.

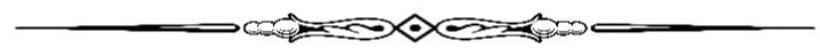

